\title{
Effect of Mixing Process Parameters and Suitability of Backbone Polymer for Aluminum Powder Injection Molding Feedstock
}

(Kesan Parameter Proses Percampuran dan Kesesuaian Polimer Tulang Belakang bagi Bahan Mentah Membentuk Suntikan Serbuk Aluminium)

\author{
A.A. AbDUllahi , I.A. ChOUdHURY*, M. AZUdDin \& N. NAHAR
}

\begin{abstract}
A suitable and cost-effective microfabrication technique for processing aluminum micropart is required, as the choice of aluminum microparts for aerospace, electronics and automobile components is preferred over other metals due to its excellent properties. Meanwhile, powder injection molding (PIM) is identified as an economical manufacturing technique for processing ceramic and micro-metal powders into microparts and or components. Therefore, this study investigates formulation and processing of aluminum PIM feedstock using a custom-made machine. The investigation is focused on the effect of mixing process parameters (powder loading, rotor speed and mixing temperature) and the suitability of the backbone polymer. The formulated PIM feedstock constituents are paraffin wax (PW), stearic acid (SA), high-density polyethylene (HDPE)/ medium-density polyethylene (MDPE) alternatively and aluminum micro-metal powder. Taguchi method is used for the design of experiments (DOEs) and analysis. In addition, response surface methodology (RSM) is employed to develop empirical viscosity models. The optimum powder-binder mixing ratio of 58:42 vol. \% with rotor speed of $43 \mathrm{rpm}$ were determined for preparing aluminum PIM feedstock using mini-lab mixer developed. The empirical model developed for aluminum PIM feedstock viscosity shows a good fit with $R^{2}$ values of 0.84 using HDPE and 0.96 for MDPE binder system. This investigation demonstrates preparation and suitability of aluminum PIM feedstock using waxbased binder system.
\end{abstract}

Keywords: Aluminum; injection molding; optimization; powder-binder mixing; viscosity

\section{ABSTRAK}

Teknik mikrofabrikasi yang sesuai dan kos efektif dalam memproses komponen mikrobahagian aluminum amat diperlukan kerana ciri yang dimiliki adalah sangat bagus dan aluminum adalah pilihan yang lebih baik berbanding logam lain dalam pembuatan komponen pada skala mikro dalam bidang aeroangkasa, elektronik dan juga automotif. Sementara itu, sistem pengacuan logam teknik suntikan serbuk (PIM) dikenal pasti sebagai teknik pembuatan yang cekap daripada segi ekonomi untuk memproses serbuk seramik dan logam kepada komponen berskala mikro. Oleh itu, penyelidikan ini mengkaji formula dan teknik pemprosesan bahan mentah aluminum PIM menggunakan mesin khas buatan sendiri. Kajian ini memberi tumpuan kepada kesan campuran pelbagai proses parameter (bebanan serbuk, kelajuan rotor dan suhu campuran) serta kesesuaian penggunaan tulang belakang polimer. Formula untuk bahan mentah PIM yang digubal adalah lilin parafin (PW), asid stearik (SA), polietilena berketumpatan tinggi (HDPE)/polietilena berketumpatan sederhana (MDPE) sebagai alternatif dan serbuk logam aluminium berskala mikro. Kaedah Taguchi digunakan untuk mereka bentuk eksperimen (DOE) dan analisis. Di samping itu, kaedah gerak balas permukaan (RSM) diguna untuk membangunkan model empirikal kelikatan. Nisbah pencampuran serbuk pengikat yang optimum ialah 58:42 vol. \% dengan kelajuan rotor 43 rpm ditentukan untuk menyediakan bahan mentah aluminum PIM menggunakan pengisar skala kecil. Model empirikal bagi kelikatan bahan mentah aluminum PIM menunjukan padanan yang baik dengan nilai $R^{2}$ iaitu 0.84 untuk bahan HDPE dan 0.96 untuk MPDE sebagai sistem pengikat. Penyelidikan ini menunjukkan cara penyediaan dan kesesuaian bahan mentah aluminum PIM menggunakan sistem pengikat berasaskan lilin.

Kata kunci: Aluminum; campuran serbuk pengikat; kelikatan; pengacuan suntikan; pengoptimuman

\section{INTRODUCTION}

Preparation of quality homogeneous feedstock is required for successful powder injection molding (PIM) process. Therefore, determination of suitable feedstock formulation and preparation becomes necessary to achieve quality part by PIM. This technique is found to be cost-effect manufacturing process for processing wide variety of engineering materials (Arifin et al.2015; Ning et al. 2015; Raza et al.2015; Zakaria et al.2014). Meanwhile, to evaluate quality of PIM feedstock, viscosity behavior and homogeneity are investigated (Jang et al.2014). This study investigates formulation and processing of aluminum PIM feedstock using custom-made machine. 
Aluminum and its alloys are used as superior materials in devices and advanced technological applications. The use of aluminum part/component in electronics devices, automotive, aerospace and defense fields (Kok 2005; Rahimian et al. 2009) is preferred over other engineering materials for its lightweight, high thermal and electrical conductivity (Tatar \& Özdemir 2010). Aluminum components also have excellent mechanical properties (Akhlaghi \& Zare-Bidaki 2009). In practical applications which demand for miniaturization and lightweight especially in hand-held devices such as laptops, cell phones and tablets are supported by aluminum microparts/ components. Low cost aluminum heat sink design is successfully developed using PIM technique (Johnson \& Tan 2004). However, processing of pure aluminum powder by PIM is rare at the moment; this may be due to challenges posed during sintering process. Although remarkable successes have been achieved by some researchers (Ahmad 2005; Liu et al. 2009, 2008) for processing aluminum and its alloy by PIM. In addition, Abdoos et al. (2014) investigated rheological properties of aluminum based feedstock and injection molding trials, which produced defect-free flat dumbbell with $\mathrm{Al}-2 \mathrm{wt} \% \mathrm{Sn}-1 \mathrm{wt} \% \mathrm{Mg}$ as starting material.

Monitoring and process control of quality products during microinjection molding $(\mu \mathrm{IM})$ is identified as a necessity. Therefore, researchers applied optimization techniques to $\mu \mathrm{IM}$ process conditions to achieve defectfree products. However, some defects encountered during $\mu \mathrm{IM}$ are non-homogenous feedstock, weld line, sink mark, voids from air trapped and incomplete cavity filling (short shot). Moreover, effects of processing parameters on molded parts quality are examined using optimization techniques, which makes it possible to account for the influence of control factors simultaneously on the target quality characteristic or response factor.

\section{MATERIALS AND METHODS}

\section{MICRO-METAL POWDER-BINDER CONSTITUENTS AND FEEDSTOCK FORMULATION}

Aluminum powder of $99.8 \%$ purity and spherical shaped particles is used for preparing the PIM feedstock. Paraffin wax based binder system is used focusing on investigating the best suitable backbone polymer for the aluminum PIM feedstock. Therefore, high density polyethylene (HDPE) and medium density polyethylene (MDPE) representing the backbone polymer in the two categories considered were used alternatively. The other components are paraffin wax (PW) and stearic acid (SA). Details of the aluminum feedstock composition is presented in Table 1 .

\section{DESIGN OF EXPERIMENT AND FEEDSTOCK PREPARATION}

This study investigates the effect of mixing process parameters on feedstock viscosity as a response factor,
TABLE 1. Powder-binder composition of the aluminum feedstock formulation

\begin{tabular}{cccc}
\hline \multirow{2}{*}{$\begin{array}{c}\text { Powder loading } \\
\text { (Vol. \%) }\end{array}$} & \multicolumn{3}{c}{ Binder constituents [Vol. \%] } \\
\cline { 2 - 4 } & $\begin{array}{l}\text { HDPE / } \\
\text { MDPE* }^{*}\end{array}$ & PW & SA \\
\hline 58 & 21.0 & 19.32 & 1.68 \\
59 & 20.5 & 18.86 & 1.64 \\
60 & 20.0 & 18.40 & 1.60 \\
\hline
\end{tabular}

* The two categories of the aluminum feedstock using HDPE / MDPE as backbone polymer were formulated as:

$\mathrm{Al}$ powder $+\mathrm{HDPE}+\mathrm{PW}+\mathrm{SA}$

$\mathrm{Al}$ powder $+\mathrm{MDPE}+\mathrm{PW}+\mathrm{SA}$

considering powder loading, rotor speed and mixing temperature as control factors. A design based on Taguchi method is adopted to investigate the effects of these mixing process parameters on the quality of feedstock. This method is chosen considering feedstock materials cost and time involved in many experimental trails for the determination of optimum powder loading. In addition, this technique has been found useful in optimization of process and product (Chua et al. 2013). The specification of the mixing parameters and levels considered for investigation are presented in Table 2. The design of experiment (DOE) is based on Taguchi $\mathrm{L}_{9}\left(3^{3}\right)$ orthogonal array and presented in Table 3.

TABLE 2. Mixing process parameters considered and level specification

\begin{tabular}{lcccc}
\hline \multirow{2}{*}{ Operation parameters } & Symbol & \multicolumn{3}{c}{ Level } \\
\cline { 3 - 5 } & & -1 & 0 & +1 \\
\hline Powder loading (\% vol.) & $\mathrm{M}_{1}$ & 58 & 59 & 60 \\
Rotor speed (rpm) & $\mathrm{M}_{2}$ & 35 & 43 & 51 \\
Mixing temperature $\left({ }^{\circ} \mathrm{C}\right)^{*}$ & $\mathrm{M}_{3}$ & 100 & 110 & 120 \\
& & {$[80]$} & {$[90]$} & {$[100]$} \\
\hline
\end{tabular}

* The value within the [ ] bracket referred to temperature at which mixing of the MDPE based feedstock was carried out

TABLE 3. $\mathrm{L}_{9}\left(3^{3}\right)$ Taguchi orthogonal array for DOE

\begin{tabular}{cccc}
\hline Run & $\mathrm{M}_{1}$ & $\mathrm{M}_{2}$ & $\mathrm{M}_{3}$ \\
\hline 1 & -1 & -1 & -1 \\
2 & -1 & 0 & 0 \\
3 & -1 & +1 & +1 \\
4 & 0 & -1 & 0 \\
5 & 0 & 0 & +1 \\
6 & 0 & +1 & -1 \\
7 & +1 & -1 & +1 \\
8 & +1 & 0 & -1 \\
9 & +1 & +1 & 0 \\
\hline
\end{tabular}

Preparation of feedstock began with the Retsch Planetary Ball Mill PM 100, followed by the use of custommade mixing mechanism to investigate the effect of the 
process parameter on the feedstock viscosity. The powderbinder mixing experimental setup is shown in Figure 1.

The custom-made mixing mechanism presented in Figure 1, illustrates a mixing chamber, heating element, flexible coupling and electric motor. The mixing chamber barrel diameter is $82 \mathrm{~mm}$ and $70 \mathrm{~mm}$ length fitted with 200 $\mathrm{W}$ concentric heating band. The rotor is developed with six blades attached to the $15 \mathrm{~mm}$ diameter shaft at $90^{\circ}$ angle of orientation, which fit into the mixing chamber. The system is powered by an electric motor with a precision control box for regulating the barrel temperature and the rotor speed within the range of 30-1350 rpm. The mixer is used for preparation of aluminum based PIM feedstock samples.

The powder-binder constituents are fed into the mixing chamber, then the mixing parameters were set via the control box.

Typically, a minimum feedstock viscosity is required for PIM. Therefore, the analysis of Taguchi signal-to- noise ratio $(S / N)$ is based on smallest-is-better and expressed as:

$$
S / N=-10 \log \frac{1}{n}\left(\sum_{i=1}^{n} y_{i}^{2}\right),
$$

where $n$ represent number of repetition for given trial; and $y_{i}$ is a measure of feedstock viscosity for particular sample at a given trail which represents the evaluation of the quality characteristic considered at the " $i$-th" repetition as denoted by the subscript " $i$.". Evaluation of $S / N$ and analysis of variance (ANOVA) of the mixing parameters considered on aluminum PIM feedstock viscosity was implemented by Minitab ${ }^{\circledR} 16$ statistical software.

In addition, response surface methodology (RSM) is often used to establish the relationship between the dependent and independent variable. RSM is a combination of DOE, regression analysis and statistical inferences. In general, the response factor and the measurable/ control factors are related as:

$$
y(x)=f\left(x_{1}+x_{2}+\ldots+x_{n-1}+x_{n}\right)+\varepsilon,
$$

where $y(x)$ represents unknown response function and the measurement random error is $\varepsilon$. If the expected response is denoted by $(E[y]=\gamma)$, then surface represented by $f\left(x_{1}\right.$ $\left.+x_{2}+\ldots+x_{n-1}+x_{n}\right)=\gamma$ is known as response surface. Meanwhile, it is sometimes less complicated to view the response surface in two-dimensional representation referred to as contour plot. The general first-order regression model is expressed as:

$$
y=\beta_{o}+\sum_{j=1}^{n} \beta_{j} x_{i, j}+\varepsilon_{i},
$$

where $\beta_{0}$ is constant; $\beta_{j}$ and is coefficient of the variable $x_{i, j}$ which denotes the $i$-th observation of the variable $x_{j}$. Therefore, the viscosity model in terms of the mixing parameters considered earlier is represented as:

$$
\eta=\beta_{o}+\sum_{j=1}^{n} \beta_{j} M_{i, j}+\varepsilon_{i}
$$

\section{RESULTS AND DISCUSSION}

\section{EFFECTS OF MIXING PARAMETERS ON THE FEEDSTOCK VISCOSITY USING HDPE BINDER SYSTEM}

The aluminum PIM feedstock viscosity measurement and computed $S / N$ of the Taguchi $\mathrm{L}_{9}\left(3^{3}\right)$ orthogonal array with three replications for each trail is presented in Table 4 for HDPE based binder system.

The effect of mixing process parameters considered on feedstock viscosity for HDPE based binder system is presented in Figure 2.

The main effect plot of the $S / N$ ratios shows that optimal mixing parameter for processing aluminum PIM feedstock based on HDPE binder system are 58 vol. \%

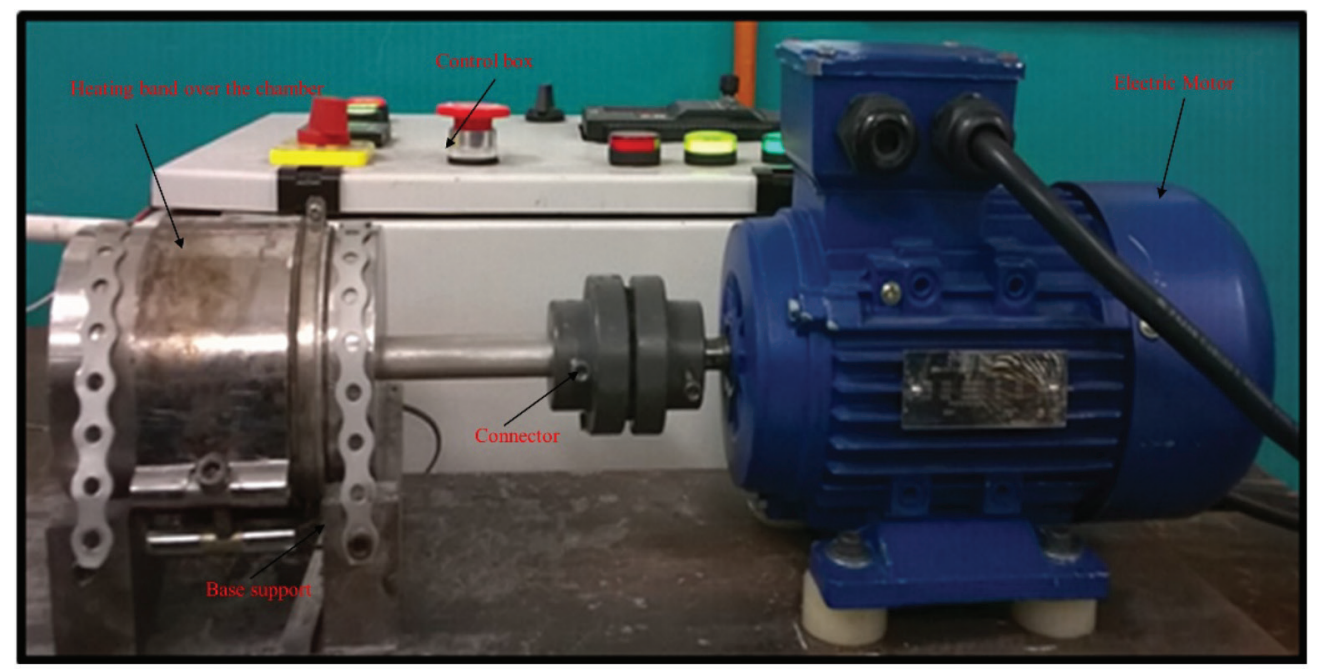

FIGURE 1. Custom-made mixing mechanism for processing PIM feedstock 
TABLE 4. Aluminum PIM feedstock viscosity and $S / N$ ratio for HDPE binder system

\begin{tabular}{cccccc}
\hline \multirow{2}{*}{ Trials } & \multicolumn{5}{c}{ Viscosity $[$ Pa.s] } \\
\cline { 2 - 5 } & $\mathrm{R} 1$ & $\mathrm{R} 2$ & $\mathrm{R} 3$ & $\mathrm{AV}$ & \\
\hline 1 & 11.12 & 11.60 & 12.35 & 11.6900 & -21.3644 \\
2 & 13.59 & 14.43 & 13.00 & 13.6733 & -22.7255 \\
3 & 12.20 & 12.56 & 13.28 & 12.6800 & -22.0678 \\
4 & 14.89 & 14.00 & 16.14 & 15.0100 & -23.5424 \\
5 & 19.38 & 18.59 & 19.88 & 19.2833 & -25.7069 \\
6 & 16.70 & 17.00 & 16.10 & 16.6000 & -24.4044 \\
7 & 23.65 & 23.44 & 25.49 & 24.1933 & -27.6802 \\
8 & 37.75 & 37.70 & 36.00 & 37.1500 & -31.4013 \\
9 & 28.17 & 30.46 & 28.80 & 29.1433 & -29.2956 \\
\hline
\end{tabular}

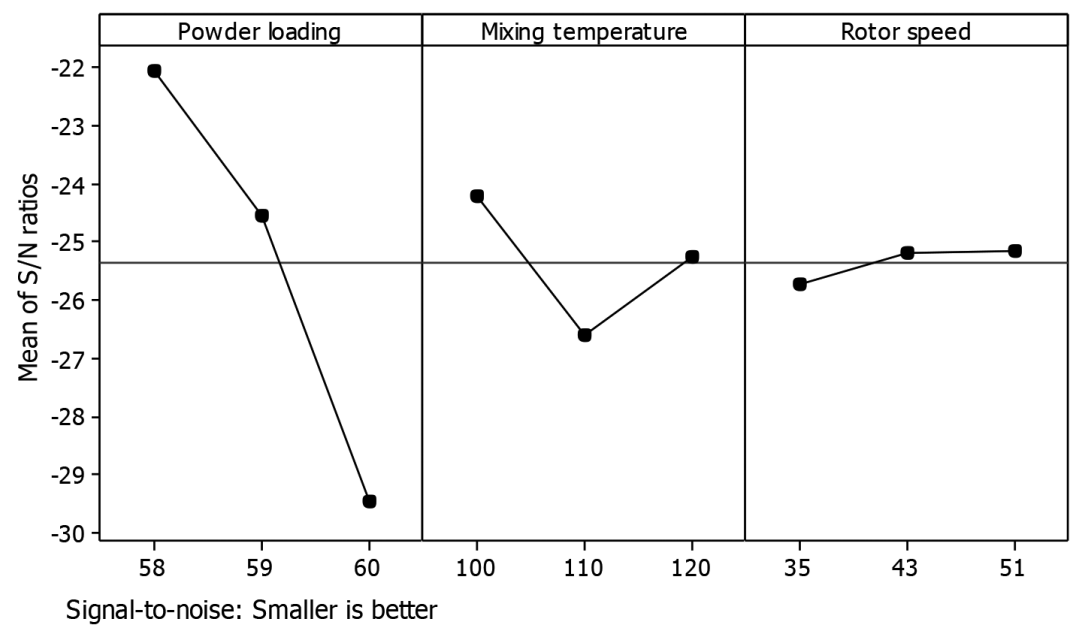

FIGURE 2. Main effects plot of $S / N$ ratios for aluminum PIM feedstock viscosity based on HDPE binder system

powder loading (level 1$), 100^{\circ} \mathrm{C}$ mixing temperature (level 1) and $43 \mathrm{rpm}$ rotor speed (level 2). This is an indication that mixing of aluminum PIM feedstock based on HDPE binder system using the mini-lab mixer developed will produce the required viscosity at the optimal operating rotor speed of $43 \mathrm{rpm}$ at powder loading of $58 \mathrm{vol} . \%$.

ANOVA of the $S / N$ ratios of the aluminum PIM feedstock viscosity based on HDPE binder system is presented in Table 5. The analysis shows the effect of input factors on viscosity. It is observed that powder loading has the most significant effect $(89.25 \%)$ followed by mixing temperature $(9.22 \%)$, the rotor speed has the least of $0.64 \%$ only.

The empirical regression model of the aluminum PIM feedstock viscosity based on HDPE binder system is determined and expressed as:

$$
\eta=-501.246+8.74056 M_{1}-0.193403 M_{2}+0.1255 M_{3} .
$$

The coefficient of determination denoted by $R^{2}$ for the PIM viscosity model is evaluated, $R^{2}=81.05 \%$ and $R^{2}$ (adj.) $=69.69 \%$ which illustrates a good fit. The contour plot of the feedstock viscosity based on HDPE based binder system vs powder loading and rotor speed is presented in Figure 3 . The graph illustrates an increase in powder loading is directly proportional to the feedstock viscosity at a given operating condition.

Prediction of mean $S / N$ and feedstock viscosity at optimal level are $-20.7275 \mathrm{~dB}$ and 9.0493 Pa.s. The correlation of the empirical model and the experimental

TABLE 5. ANOVA of $S / N$ for feedstock viscosity based on HDPE binder system

\begin{tabular}{lccccc}
\hline Factors & DF & SS & MS & F & Contribution (\%) \\
\hline Powder loading & 2 & 85.185 & 42.593 & 99.748 & 89.247 \\
Rotor speed & 2 & 0.615 & 0.308 & 0.720 & 0.644 \\
Mixing temperature & 2 & 8.796 & 4.398 & 10.300 & 9.215 \\
Error & 2 & 0.854 & 0.427 & & 0.895 \\
Total & 8 & 95.449 & & & \\
\hline
\end{tabular}




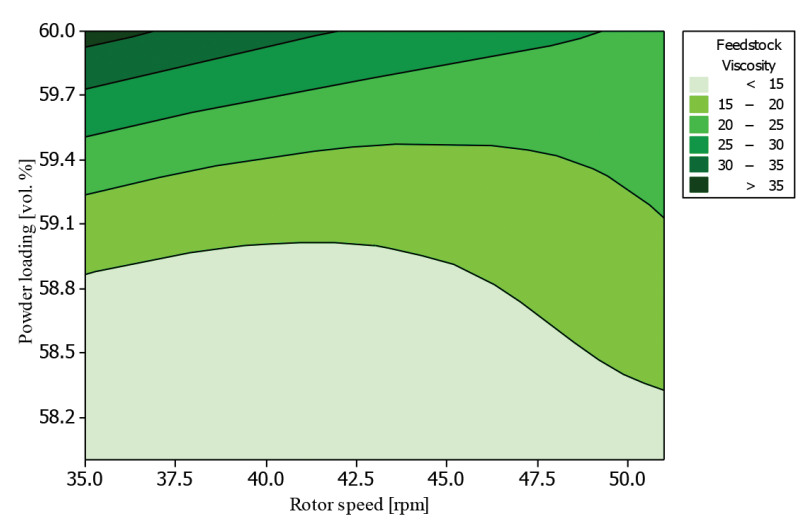

FIGURE 3. Contour plot of aluminum PIM feedstock viscosity based on HDPE binder system

measured aluminum PIM feedstock viscosity for HDPE binder system is presented in Figure 4. The graph illustrates the accuracy of the predicted model developed compared to the experimentally observed viscosity.

\section{EFFECTS OF MIXING PARAMETERS ON THE FEEDSTOCK VISCOSITY USING MDPE BINDER SYSTEM}

Table 6 presents the viscosity measurement and computed $S / N$ of Taguchi $\mathrm{L}_{9}\left(3^{3}\right)$ orthogonal array with three replications for each trail of MDPE based binder system.

Similarly, the effect of mixing process parameters considered on feedstock viscosity for MDPE based binder system is presented in Figure 5. The main effect plot of the $S / N$ ratios shows that optimal mixing parameter for processing aluminum PIM feedstock based on MDPE binder system are 58 vol. \% powder loading (level 1), $80^{\circ} \mathrm{C}$ mixing temperature (level 1 ) and $43 \mathrm{rpm}$ rotor speed (level 2). The $S / N$ ratios plot of the effects indicates that mixing of aluminum PIM feedstock using mini-lab mixer developed will produce the required viscosity at the optimal operating rotor speed of $43 \mathrm{rpm}$ at powder loading of $58 \mathrm{vol} . \%$.
ANOVA of the $S / N$ ratios of the PIM feedstock viscosity based on MDPE binder system is presented in Table 7 . The analysis shows that the contribution of each process parameter with $94.46 \%$ powder loading, $4.83 \%$ mixing temperature and $0.27 \%$ rotor speed. Therefore, rotor speed is less significant at the specified 95\% confidence level considered.

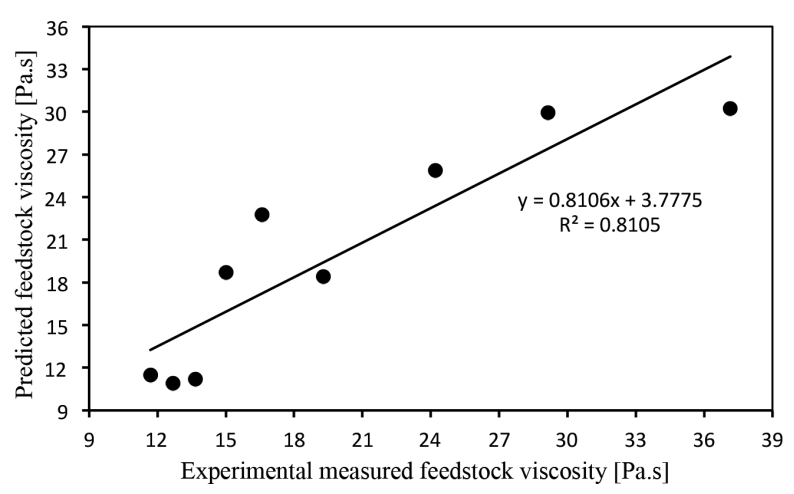

FIGURE 4. Correlation between predicted and experimental feedstock viscosity based on HDPE binder system

TABLE 6. Aluminum PIM feedstock viscosity and $S / N$ ratios for MDPE binder system

\begin{tabular}{cccccc}
\hline \multirow{2}{*}{ Trials } & \multicolumn{5}{c}{ Viscosity [Pa.s] } \\
\cline { 2 - 5 } & $\mathrm{R} 1$ & $\mathrm{R} 2$ & $\mathrm{R} 3$ & $\mathrm{AV}$ & \\
\hline 1 & 12.96 & 12.90 & 12.72 & 12.86 & -22.1851 \\
2 & 14.72 & 15.20 & 14.93 & 14.95 & -23.4936 \\
3 & 13.80 & 14.43 & 14.07 & 14.10 & -22.9858 \\
4 & 18.73 & 18.50 & 18.00 & 18.41 & -25.3023 \\
5 & 24.38 & 23.60 & 24.62 & 24.20 & -27.6777 \\
6 & 22.73 & 23.65 & 24.12 & 23.50 & -27.4240 \\
7 & 30.40 & 30.90 & 31.10 & 30.80 & -29.7714 \\
8 & 35.41 & 35.87 & 34.95 & 35.41 & -30.9830 \\
9 & 33.93 & 34.79 & 33.88 & 34.20 & -30.6812 \\
\hline
\end{tabular}

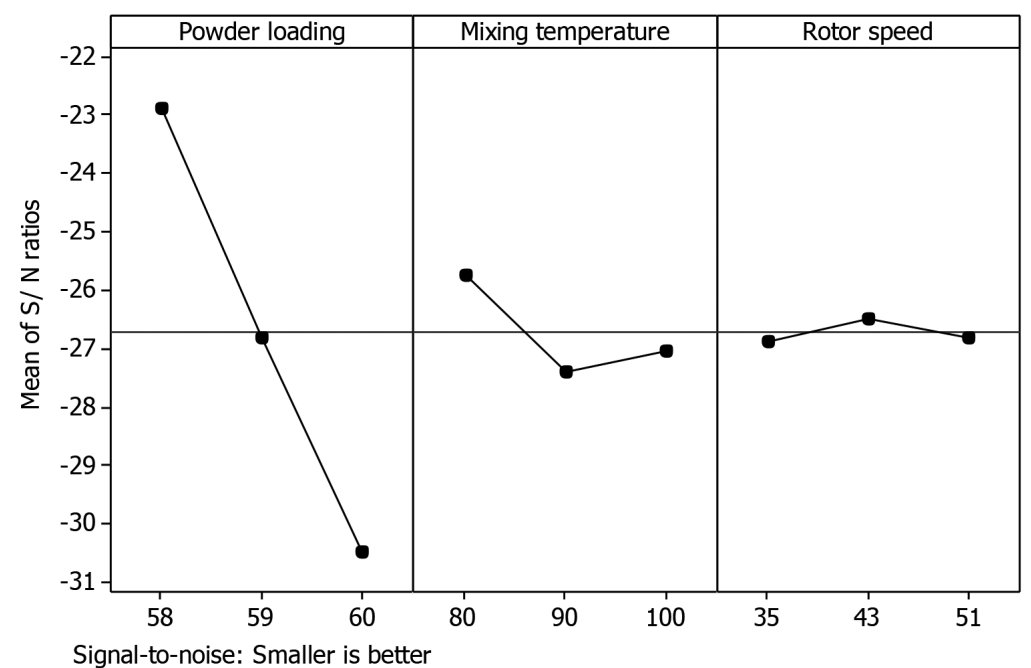

FIGURE 5. Main effect plot of $S / N$ ratios for aluminum PIM feedstock viscosity based on MDPE binder system 
TABLE 7. ANOVA of $S / N$ for feedstock viscosity based on MDPE binder system

\begin{tabular}{lccccc}
\hline Factors & DF & SS & MS & F & Contribution $(\%)$ \\
\hline Powder loading & 2 & 86.448 & 43.224 & 212.926 & 94.461 \\
Rotor speed & 2 & 0.243 & 0.122 & 0.599 & 0.266 \\
Mixing temperature & 2 & 4.420 & 2.210 & 10.887 & 4.830 \\
Error & 2 & 0.406 & 0.203 & & 0.444 \\
Total & 8 & 91.517 & & & \\
\hline
\end{tabular}

The empirical multiple regression model for aluminum PIM feedstock viscosity based on MDPE binder system is developed and expressed as:

$$
\eta=-564.294+9.75 M_{1}-0.055625 M_{2}+0.162167 M_{3}
$$

The $R^{2}=96.34 \%$ and $R^{2}(\operatorname{adj})=.94.15 \%$ for aluminum PIM viscosity model using MDPE binder system illustrates a good fit. This is supported by the fact that a good fitted regression model has $R^{2}$ value between 0.7 and 1.0 (Montgomery \& Runger 2014; Myers et al. 2016). The contour plot of the aluminum PIM feedstock viscosity based on MDPE based binder system vs powder loading and rotor speed is presented in Figure 6.

Prediction of mean $S / N$ and feedstock viscosity at optimal level are $-21.6881 \mathrm{~dB}$ and 10.8622 Pa.s. The correlation of the empirical model and the experimental measured PIM feedstock viscosity for MDPE binder system is presented in Figure 7. The graph shows the data trend and accuracy of the developed model to the experimental values of the aluminum PIM viscosity. As the $R^{2}$ is high both the predicted and experimental values are close and accuracy is higher.

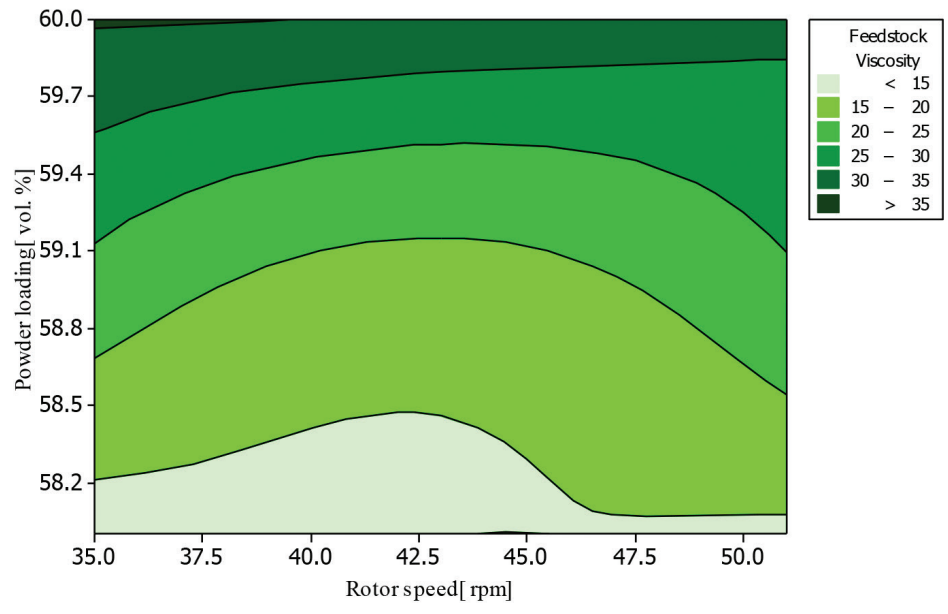

FIGURE 6. Contour plot of aluminum PIM feedstock viscosity based on MDPE binder system

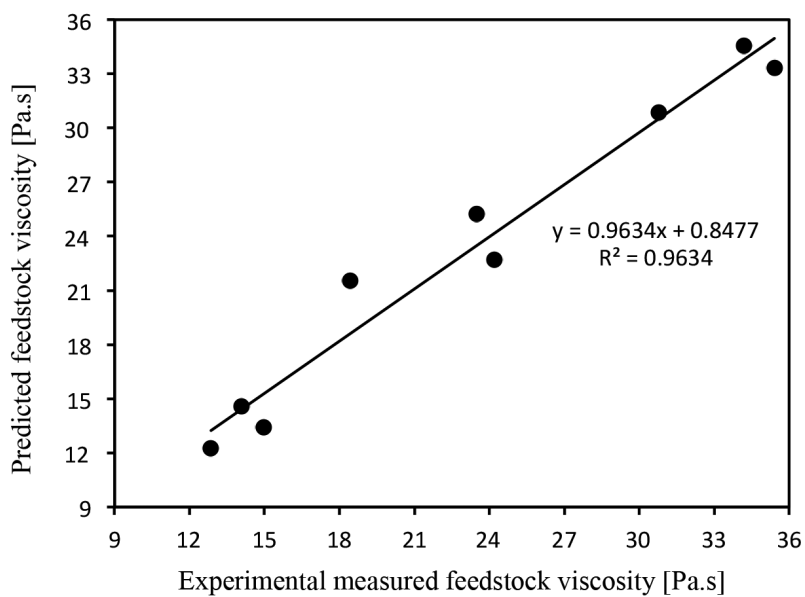

FIGURE 7. Correlation between predicted and experimental feedstock viscosity based on MDPE binder system 


\section{CONCLUSION}

Optimum operating conditions of mixing aluminum powder and paraffin wax binder system based on HDPE and MDPE backbone polymer were investigated using a custommade mixing mechanism developed for preparation of PIM feedstock. Therefore, the conclusions of the investigation are summarized as follow:

Optimal rotor speed of $43 \mathrm{rpm}$ and powder loading of $58 \mathrm{vol} . \%$ were determined for both HDPE and MDPE binder system of aluminum PIM feedstock.

The feedstock prepared show pseudoplastic flow behavior but the use of HDPE binder system is more suitable than MDPE in terms of various sample behavior during processing.

Aluminum PIM feedstock viscosity strongly depends on material properties with a contribution from powder loading by $89.25 \%$ using HDPE and $94.46 \%$ for MDPE binder system.

Good fit empirical models for aluminum PIM feedstock viscosity prediction have been developed with $R_{2}$ of 0.84 using HDPE and $R_{2}$ of 0.96 for MDPE binder system.

\section{ACKNOWLEDGEMENTS}

The authors would like to acknowledge the financial support from University of Malaya, 50603 Kuala Lumpur, Malaysia; through the University of Malaya Research Grant (UMRG)- (RP020-2012A) and (RP020-2012B) in carrying out this research. In addition, the provisions of facilities, technical contributions by the members of engineering faculty, University of Malaya, Malaysia is greatly appreciated.

\section{REFERENCES}

Abdoos, H., Khorsand, H. \& Yousefi, A.A. 2014. Torque rheometry and rheological analysis of powder-polymer mixture for aluminum powder injection molding. Iranian Polymer Journal 23(10): 745-755.

Ahmad, F. 2005. Rheology of metal composite mixes for powder injection molding. International Journal of Powder Metallurgy 41(6): 43-48.

Akhlaghi, F. \& Zare-Bidaki, A. 2009. Influence of graphite content on the dry sliding and oil impregnated sliding wear behavior of Al 2024-graphite composites produced by in situ powder metallurgy method. Wear 266(1-2): 37-45.

Arifin, A., Sulong, A.B., Muhamad, N., Syarif, J. \& Ramli, M.I. 2015. Powder injection molding of HA/Ti6Al4V composite using palm stearin as based binder for implant material. Materials \& Design 65: 1028-1034.

Chua, M.I.H., Sulong, A.B., Abdullah, M.F. \& Muhamad, N. 2013. Optimization of injection molding and solvent debinding parameters of stainless steel powder (ss3161) based feedstock for metal injection molding. Sains Malaysiana 42(12): 1743-1750.
Jang, J.M., Lee, H., Lee, W., Kim, Y.I., Ko, S.H., Kim, J.H., Lee, J.S. \& Choi, J.P. 2014. Evaluation of feedstock for powder injection molding. Japanese Journal of Applied Physics 53: $5 \mathrm{~S} 3$

Johnson, J.L. \& Tan, L.K. 2004. Metal injection molding of heat sinks. Electronics Cooling 10(4).

Kok, M. 2005. Production and mechanical properties of $\mathrm{Al}_{2} \mathrm{O}_{3}$ particle-reinforced 2024 aluminium alloy composites. Journal of Materials Processing Technology 161(3): 381-387.

Liu, Z.Y., Kent, D. \& Schaffer, G.B. 2009. Powder injection moulding of an Al-AlN metal matrix composite. Materials Science and Engineering a-Structural Materials Properties Microstructure and Processing 513(14): 352-356.

Liu, Z.Y., Sercombe, T.B. \& Schaffer, G.B. 2008. Metal injection moulding of aluminium alloy 6061 with tin. Powder Metallurgy 51(1): 78-83.

Montgomery, D.C. \& Runger, G.C. 2014. Applied Statistics and Probability for Engineers (6th ed.). New York: John Wiley $\&$ Sons, Inc.

Myers, R.H., Montgomery, D.C. \& Anderson-Cook, C.M. 2016. Response Surface Methodology: Process and Product Optimization using Designed Experiments. New York: John Wiley \& Sons.

Ning, W.Y., Muhamad, N., Sulong, A.B., Fayyaz, A. \& Raza, M.R. 2015. Effects of vanadium carbide on sintered WC$10 \%$ Co produced by micro-powder injection molding. Sains Malaysiana 44(8): 1175-1181.

Rahimian, M., Ehsani, N., Parvin, N. \& Baharvandi, H.R. 2009. The effect of particle size, sintering temperature and sintering time on the properties of $\mathrm{Al}-\mathrm{Al}_{2} \mathrm{O}_{3}$ composites, made by powder metallurgy. Journal of Materials Processing Technology 209(14): 5387-5393.

Raza, M.R., Sulong, A.B., Muhamad, N., Akhtar, M.N.\& Rajabi, J. 2015. Effects of binder system and processing parameters on formability of porous Ti/HA composite through powder injection molding. Materials \& Design 87: 386-392.

Tatar, C. \& Özdemir, N. 2010. Investigation of thermal conductivity and microstructure of the $\alpha-\mathrm{Al}_{2} \mathrm{O}_{3}$ particulate reinforced aluminum composites (A1/A12O3-MMC) by powder metallurgy method. Physica B: Condensed Matter 405(3): 896-899.

Zakaria, H., Muhamad, N., Sulong, A.B., Ibrahim, M.H.I. \& Foudzi, F. 2014. Moldability characteristics of $3 \mathrm{~mol} \%$ Yttria stabilized zirconia feedstock for micro-powder injection molding process. Sains Malaysiana 43(1): 129-136.

Manufacturing Systems Integration

Department of Mechanical Engineering, University of Malaya 50603 Kuala Lumpur, Federal Territory

Malaysia

*Corresponding author; email: imtiaz@um.edu.my

Received: 22 May 2016

Accepted: 17 August 2016 